ljtihad: Jurnal Wacana Hukum Islam dan Kemanusiaan

Vol. 21, No. 2 (2021), pp. 213-230, doi : 10.18326/ijtihad.v21i2.213-230

\title{
The urgency to reform the kafāla system in the sake of human rights of Indonesia domestic workers
}

\author{
Anggita Doramia Lumbanraja, Yusriyadi \\ Universitas Diponegoro \\ E-mail: anggitalumbanraja@live.undip.ac.id,yusriyadi@lecturer.undip.ac.id \\ DOI: 10.18326/ijtihad.v21i2.213-230
}

The Maslaha of Indonesian foreign domestic workers in Saudi Arabia still become the biggest concern. Even though Saudi Arabia has reformed the Labor Law on the kafäla system, unfortunately, it is excluded from foreign domestic workers. Therefore, it urges legal research to examine the kafâla system in Saudi Arabia from an Islamic and human rights perspective. Then, to provide the strategic plans for the Indonesian government to do. This research uses doctrinal research methods through the literature study and analyzed with the qualitative descriptive method. From the Islamic law perspective, although the kafäla system in Saudi Arabia is derived from the Qur'an and the Sunnah. Kafäla system in Saudi Arabia is regulated on Resolution no. 310. However, in practice, Kafil abuses their strong position (83. QS. Al-Mutaffifin) in treating workers arbitrarily. In other words, there is a deviation from the philosophical values of maqassid ash-syariah. From the international law perspective, this practice is against the mandate of the UDHR and ICCPR. Therefore, it is highly recommended that Indonesia push Saudi Arabia to replace individual sponsorship as kafil for Indonesian domestic workers. It is better to establish a special guaranteed institution for domestic workers from Indonesia in Saudi Arabia integrated with the SPSK system.

Kemaslahatan (maslaha) pekerja domestik asing asal Indonesia di Arab Saudi masih menjadi persoalan. Reformasi Undang-Undang Ketenagakerjaan yang dilakukan oleh Arab Saudi terhadap sistem kafäla, tidak berlaku bagi pekerja domestik asing. Oleh karena itu, perlu adanya kajian penelitian hukum yang mengkaji tentang sistem kafäla di Arab Saudi dalam perspektif Hukum Islan dan Hak Asasi Manusia untuk kemudian dapat dirumuskan kebijakan hukum apa yang sebaiknya diambil oleh pemerintah Indonesia. Penelitian ini menggunakan metode penelitian doktrinal. Data penelitian dikumpulkan melalui metode studi kepustakaan dan dianalisis dengan metode analisis data deskriptif kualitatif. Ditinjau dari Hukum Islam, meskipun sistem kafäla di Arab Saudi didasarkan 
pada Sharīah yang bersumber pada al-Qur'ān dan as-Sunnah. Sistem kafäla di Arab Saudi diatur di dalam Resolusi 310. Namun dalam prakteknya, Kafil menyalahgunakan posisi mereka yang kuat (83. QS. Al-Mutaffifin) dalam memperlakukan pekerja secara sewenang-wenang tanpa memperhatikan kemaslahatan pekerja. Dengan kata lain ada penyimpangan terhadap nilai-nilai filosofis maqāsid asysyariah. Hal ini mendapat kritikan tajam dari sisi hukum internasional yang berbenturan dengan amanat UDHR dan ICCPR. Penelitian ini merekomendasikan agar Pemerintah Indonesia mendesak Pemerintah Arab Saudi untuk tidak menempatkan pihak individu sebagai kafil bagi para pekerja domestik asal Indonesia. Sebaiknya didirikan sebuah lembaga penjaminan khusus bagi pekerja domestik asal Indonesia di Arab Saudi yang terintegrasi dengan Sistem SPSK.

Keywords: Indonesia domestic workers; kafäla system; labour law reform

\section{Introduction}

The Kafäla system (نظام الكفالة-nizam al-kafäla) was established as a legal policy in the form of legislation by the GCC (the Gulf Cooperation Council) countries around the 1950s, to control the large flow of migrant workers into the coutries of GCC (Migrant Forum in Asia (MFA), 2012, p. 1). The discovery of oil in the GCC countries since the 1930s has become a magnet for migrants and refugees to work and find a decent living in these countries because of their enormous economic potential (AlShehabi, 2021, p. 5). Since the 1950's they began to arrive in the GCC countries. Even their numbers are increasing more and more until they reach 30 percent of the total population in Saudi Arabia and occupy 49 percent of the workforce in Saudi Arabia. Of course, this is troubling the governments of the GCC countries (Alzahrani, 2014, p. 171). Then they set the Kafäla system as a labor guarantee system to control the number of migrants entering and put the interests of their citizens above the interests of the migrants (Al-Ghanim, 2015, p. 7).

The Kafäla system in Saudi Arabia is based on the Qur'an and as-Sunnah by the shariah applied in that country. The Kafala system, in the context of employment law, is a form of agreement between a guaranteed person (makfüi) and a guarantor (Kafil). In Islamic law, Kafäla in the context of guarantee is known in the form of ensuring a person's obligation to pay a debt or an agreed amount of money (Kafäla bi-al-mâa). It can also be in the form of guaranteeing the presence of a particular person at a specific time and place (Kafäla bi-al-naf) or in ensuring the presence of a person in a legal case by paying a security deposit (Kafala bi-al-wajh). Kafäla is also known in the form of guarantees in the delivery of goods (Kafäla 
The urgency to reform the kafāla system in the sake of human...(Anggita Doramia Lumbanraja, et.al)

bi-al-tastim) and also in the form of guarantees in the purchase of goods sold (Kafäla bi-aldarak) (Jureidini and Hassan, 2020, p. 94).

In November 2020, the Ministry of Human Resources and Social Development of Saudi Arabia announced plans to change the Kafäla system of employment law, which gives foreign workers the right to change jobs by transferring their sponsor (Kafil) from one employer to another. Leave and re-enter Saudi Arabia without having to go through their employer's approval, and in the case of an exit permit, that does not require the employer's approval (Al Jazeera, 2020) This policy will be effective starting March 2021 (Al Jazeera, 2021). The reforms, introduced as ministerial resolutions and available via the online platforms Absher and Qiwa, only partially address two of the five critical elements of the Kafäla system. However, it is miserable that this policy is not applied to the lowskilled worker segment, such as Foreign Domestic Workers. This has received scathing criticism from various circles, especially from human rights and workers' rights activists, because this labor law reform does not solve the real source of the problem, namely legal protection for foreign domestic workers who occupy 80 percent of the private sector workforce in Indonesia. Saudi Arabia. They have been subjected to cruel treatment, and their employers do not fufill their rights. They are even at high risk of being abused (3.7 million domestic workers face severe harassment, including workers' rights and human rights are not fulfilled) (Human Right Watch (HRW), 2021).

This phenomenon deserves international attention. Based on the data obtained, there are many violations committed by the employer as a Kafil that does not pay attention to the benefit of foreign domestic workers. Indonesian Migrant Workers in Saudi Arabia also experience this. According to the Indonesian Embassy in Riyadh, there were many employment cases experienced by Indonesian Migrant Workers in Saudi Arabia, as described in Table 1. 
Table 1.

Number of employment cases of Indonesian migrant workers in Saudi Arabia (Okezone, 2021)

\begin{tabular}{lc}
\hline \multicolumn{1}{c}{ Case Type } & $\begin{array}{c}\text { Number of } \\
\text { Cases }\end{array}$ \\
\hline the employment agreement has expired, but the employer has not returned & 205 \\
Indonesian migrant workers come on a visit visa but end up in a dispute & 131 \\
with the employer & 110 \\
lost contact (no news) & 97 \\
the work agreement has expired, but the salary is not paid & 594 \\
Indonesian migrant workers run away from employers & \\
\hline
\end{tabular}

The cases that occur in Table 1 are because the Saudi Arabian government does not enforce provisions that protect workers' rights from employers in this case acting as a guarantor (Kafil). If there is a violation of workers' rights or violence that workers experience, they prefer to remain silent because they are afraid of their Kafil, including the threat of deportation (Azhari, 2016, p. 69). In the perspective of Islamic law. This is against benefit and Sharīah as the foundation of this Kafäla System. Meanwhile, from the perspective of international law, this violates workers' rights and the human rights of workers.

There have been several previous studies examining the problems of the Kafäla system in the context of labor law. Research conducted by Abdoulaye Diop, Trevor Johnston \& Kien Trung Le in 2015 examines why reforms to the Kafäla system are challenging to achieve. This research was conducted using experimental data and surveys in the Qatar region (Diop, Johnston and Le, 2015, p. 116). In 2019, Abdul Hanif researched Kafäla in the frame of benefit from a philosophical perspective (Hanif, 2019, p. 88). In the same year, in 2019, Rachel Silvey and Rhacel Parreñas conducted a study on the portrait of migrant workers from the region of Southeast Asian countries, including Indonesia, who is suspected of being a money machine for their families and countries, but whose legal interests do not get the same protection at all (Silvey and Parreñas, 2020, p. 3457).

From the series of studies above, no research examines the Kafäla system from the perspective of Islamic Law and Human Rights. This study aims to examine the Kafāla system in Saudi Arabia from the perspective of Islamic Law and Human Rights from 
The urgency to reform the kafāla system in the sake of human...(Anggita Doramia Lumbanraja, et.al)

International Law. From these two perspectives, it can be seen how important it is to reform the Kafäla System in the Protection of Human Rights for Foreign Domestic Workers. From the results of this study, it is hoped that it can produce recommendations that can be a contribution of thought for the Government of Indonesia to immediately take several strategic policies in the legal field to stimulate reform of the Kafäla system in Saudi Arabia. This research is fundamental to do, as one of the efforts to solve the labor and humanitarian problems of Indonesian Migrant Workers in Saudi Arabia has been challenging to overcome so far.

\section{Method}

This research is doctrinal research conducted by literature study. The legal materials used include statutory regulations, books, and scientific journals both nationally and internationally, and electronic articles on the Kafäla System as an employment guarantee system. All data collected will be analyzed using descriptive qualitative data analysis method to examine the Kafäla system in Saudi Arabia from the perspective of Islamic Law and International Law. This analysis hopes there should be a reform of the Kafäla System in Saudi Arabia in the Protection of Human Rights for Foreign Domestic Workers and what changes are expected from the reform. From here it will be obtained recommendations can be given to the Government of Indonesia to stimulate the effectiveness of this reform of the Kafäla system to protect the interests of Indonesian Domestic Workers in Saudi Arabia.

\section{Kafāla system in Islamic law perspective}

The term 'Kafäla' has a broad semantic scope in Arabic (kä́f - fä - làm (كفل) which means to feed, support, guarantee or guarantee; hence 'Kafäla' refers to guarantee, guarantee, security or sponsorship (Wehr, 1994, p. 976). In terms known in Shari'a, Kafäla is also known in terms of al-Dhaman (guarantee), hamalah (burden), and za'amah (dependant) (Suhendi, 2002, p. 25). The Kafäla system is a derivative of customs in Islamic law. Kafäla has its roots in Shariah, where one party (Kafil) provides legal guarantees for the other party (makful). Basically, the concept of a guarantee is almost similar to the idea of 'surety', known globally (Lloyd, 1917, p. 40). 
The Kafäla system is based on the Qur'an and as-Sunnah. In the Qur'an we can find it in the QS. An-Nahl verse 91 which contains provisions for keeping promises or oaths. This is the underlying root of Kafäla. It is further narrated in QS. Yusuf Verse 72 which provides a guarantee against something promised by the Prophet Yusuf a gift in the form of food as heavy as a camel's load to the person who manages to find the king's cup. In addition, there are also in QS. Al-Isra' Verse 92 where Allah and the angels are the guarantee of Allah's presence (Foster, 2001, p. 140).

In the course of history, the contemporary Kafala agreement is known in the Majalla, the codification of civil law owned by the Ottoman Empire (Ottoman Civil Code) of the Hanafi School. The modern concept of Kafäla at this time is strongly dominated by the practice of Kafäla in this Majalla codex. Provisions regarding Kafāla include Article 613 (Kafäla bi-alnaf), 614 (Kafäla bi-al-mä), 615 (Kafäla bi-al-taslìm), 651 (Kafäla bi-al-darak), 618, and 634 (due to the agreement) Majalla Codex (Foster, 2001, p. 141).

The kafäla system has become a shortcut to regulate the labor problems of migrants in the Gulf Cooperation Council (GCC) countries of Bahrain, Kuwait, Oman, Qatar, Saudi Arabia, and the United Arab Emirates. Since the discovery of large-scale oil, these countries are increasingly dependent on labor imported abroad (Winckler, 2010). This is because the GCC countries have limitations in terms of Human Resources but are rich in capital. GCC countries even bring in ready-made workers (both experts, high-skilled consultants, to lowskilled workers) from Middle Eastern, Western and Asian countries (Baldwin-Edwards, 2011, p. 51).

As the number of migrant workers entering the territory of the GCC countries increases, it affects the concept of Kafäla. The modern idea of Kafäla in this era requires a migrant worker to enter the part of the GCC countries only for temporary work (not for permanent). For their life, while working in GCC countries, migrant workers need a place to live that depends on local sponsors (KafiD. Thus, the Sponsors (Kafid) are responsible for the living and working conditions of the workers, which may include housing and the necessities of daily living. In addition, a migrant worker, when going out of the country or about to change jobs, must obtain a sponsor's permission (by written letter) (Murray, 2012, p. 467). 
The urgency to reform the kafāla system in the sake of human...(Anggita Doramia Lumbanraja, et.al)

Kafil must report to immigration authorities if a migrant worker leaves his job and must ensure that the worker leaves the country after the contract expires, including paying for the flight home. Often Kafil has complete control and control over migrant workers by confiscating their passports and travel documents, although this is an illegal practice by law. This unlawful practice places migrant workers entirely dependent on their Kafil for livelihood and residence (Migrant Forum in Asia (MFA), 2012, p. 1).

Basically, the concept of Kafäla is very commendable, even more so when viewed from the philosophical and historical aspects. However, because the Kafäla system is given to individuals or companies, on the other hand, the government's supervision and intervention on the Kafäla system is very weak and limited. So began to emerge various legal and social problems that arise in the practice of this Kafäla system (Shaham, 2008, p. 4).

Cases of abuse arise from an imbalance of power between sponsors (Kafil) and workers. This is because countries in the Middle East are less responsive in ratifying international agreements that protect workers, including not approving ILO Convention No. 189 concerning Domestic Workers. This becomes very important to force the Government to set minimum wages, abolish forced labor, ensure decent working conditions, and seek legal protection for workers (Robinson, 2021).

As a result, workers face many offenses under the Kafäla system. These include restrictions on movement and communication made by the employer to workers. Employers unilaterally forcibly confiscate Workers' passports, visas, and telephones, even locking domestic workers in their homes. Non-domestic workers often live in overcrowded dormitories, which has become especially dangerous during the coronavirus pandemic. Workers are at risk of contracting COVID-19 in dormitories, and many do not have adequate health care. In addition, there is debt bondage wrapped around the workers (Robinson, 2021).

Although most host countries require employers to pay a recruitment fee, this fee is passed on to the practice workers. Thus forcing workers to take out loans to pay these fees to recruiters. Employers sometimes reduce or withhold workers' wages, ostensibly to pay recruiters. This fraud then developed into forced labor. And made worse by their ignorance when they signed the employment agreement. Employment agreements are often made in a language that workers do not understand, so they are not aware they will receive meager 
Ijtihad: Jurnal Wacana Hukum Islam dan Kemanusiaan, Volume 21, No. 2, Desember 2021: 213-230

wages, poor working conditions, and the non-fulfillment of workers' rights (Robinson, 2021).

Another legal issue is that Sponsors sometimes illegally sell worker visas to other employers while remaining the official sponsor. The new employer may not comply with the exact requirements as the original, require a different type of work, or provide lower wages. This causes Workers to rely heavily on sponsors to remain in the country legally, as sponsors can cancel their status for any reason (Robinson, 2021).

These illegal practices further deviate from the true essence of the Kafäla System. Many Employers cheat, as written in 83. QS. Al-Mutaffifin. In other words, this deviation from the Kafäla System has deviated from the goal of the Sharïab itself, which is to guarantee the benefit of humans, in this case, the maslaha of the workers. The objectives of Sharìah (مقاصد الشريعة), maqạsid ash-syari’ah) include maintaining the mașlaḥa of religion (bifdzud din), the maslaha of reason (bifdzul a'q), the maslaha of the soul (bifdzun nafs), the maslaha of offspring (bifdzun nas), and the maslaha of property (hifdzul mal), (Kurniawan, 2018, p. 179). Violations of the Islamic law that employers violate include deviating from the goals of Shari'ah in terms of maintaining the maslaha of the soul, the maslaha of the wealth, and the maslạ̧a of offspring.

Islam is explicitly stated in 4. QS. An-Nisa 'verse 92-93 prohibits killing. However, in reality, there have been many cases of violence and abuse by the Employers, which have resulted in the death of the Workers. Indonesian Migrant Workers are vulnerable to violence and abuse that lead to death in Saudi Arabia. This happened to Sumiyati, an Indonesian Migrant Worker from Demak, Central Java, who died in Saudi Arabia in 2010 due to abuse by her employer. When the body was returned, it was found that there were stab wounds, beatings, and even burns that his employer allegedly committed. But unfortunately, the Qisas Law (2. QS. Al-Baqarah verses 178-179) is not applied to punish Sumiyati's employer (Putranto, 2018).

The case was experienced by Arini Binti Ayas (Indonesian Migrant Worker in Saudi Arabia), who was a victim of the Criminal Acts of Trafficking in Persons for ten years and was raped by her employer (Kirom, 2021). This contradicts the principle of the maslaha of offspring (hifdzun nasl) in 24. QS. An-Nūr verses 30 and 17. QS. Al-Isra' verse 32 (Dahlan 
The urgency to reform the kafāla system in the sake of human...(Anggita Doramia Lumbanraja, et.al)

et al., 1999, pp. 66-67). But unfortunately, Arini Binti Ayas did not get fair treatment. The employer is not punished according to the provisions in 24. QS. An-Nūr verse 2.

The practice of setting workers' meager wages and the imposition of labor placement fees on workers is a violation of the benefit of honorary property (bifdzul mal). In 2. QS. Al-Baqarah verses 275-284 confirm that Muslims are prohibited from taking usury or riba from others. Practices that charge labor placement fees to workers are essentially riba (Foster, 2001, p. 146). Therefore this is against the Islamic Shariah.

From the description above, we can see that there is a need for improvement in the practice of the Kafala System. Primarily examines the placement of individuals as sponsors (KafiD. The factual situation and the content of the employment agreement that places the Sponsor (Kafil) have great control over their workers, making the violations against the Islamic Shariah increase.

\section{Kafāla system in international law perspective}

The Saudi Arabian Government's legal policy regarding Domestic Workers is stipulated in Resolution No.310 of 2013 on the Household Regulation on Services Workers and Similar Categories. However, this provision does not meet the requirements of the ILO Convention No. 189 concerning Domestic Workers. This is because the Government of Saudi Arabia has not ratified the convention (International Trade Union Confederation (ITUC), 2017, p. 14).

Resolution 310 regulates the protection of domestic workers about working time in household work by stipulating daily and weekly rest times and the employer's obligation to pay sick leave and annual leave. However, the provisions remain under the conditions required by Article 10 of Convention No. 189. Resolution 310 does not expressly guarantee equal treatment between households and other workers concerning regular work hours. Employers are still allowed to require their workers to work 15 hours per day and not compensate overtime (International Trade Union Confederation (ITUC), 2017, p. 18).

The government of Saudi Arabia makes special regulations regarding Migrant Workers. The rules are explicitly distinguished for workers in the private sector and domestic workers. Employment in the private sector is regulated in Royal Decree No. M/51 of 2005 
(Labour Law) Ministerial Decision No. 310 of 1434 H, 2013 regulating the employment of domestic workers. There are several differences in the guarantee system for the two types of regulations. In terms of recruitment, the law regarding domestic workers does not explicitly prohibit recruitment fees from being charged to workers. Still, it states that employers are not allowed to deduct workers' wages to pay for the recruitment costs. In the regulations governing workers in the private sector, charging recruitment fees to workers is strictly prohibited. Then, on the issue of passport confiscation by the employer. The domestic worker regulations do not explicitly state that employers are not permitted to confiscate passports belonging to domestic workers. Employers are strictly prohibited from seizing workers' passports in the private sector worker regulation. Failure to do so will result in a fine of 5,000 Riyals (or approximately US\$1300). Regarding the minimum wage, both regulations do not stipulate the minimum wage for workers. In terms of working hours, in the rules concerning domestic workers, the hours of domestic workers are above 15 hours per day, including rest periods. Meanwhile, the regulation on workers in the private sector regulates the working hours of workers in the private sector as much as 8 hours of work per day or the equivalent of 48 hours per week. Regarding overtime pay, the domestic worker regulations do not regulate at all. Meanwhile, worker regulations in the private sector stipulate that workers will be paid 150 percent of the worker's hourly wage (International Labour Organization (ILO), 2019).

In terms of sponsorship and changing employers, the domestic worker regulations allow for changing employers or their guarantors at any time, provided the employer's permission is available. However, it is allowed not with the consent of the employer if: The employer does not pay salary for three consecutive months, the employer does not pick up the worker within 15 days after the arrival of the migrant worker, the employer fails to issue the worker's residence permit, or the worker's stay permit has expired, the employer sends domestic workers to work for other people who are not relatives of the employer, the employer assigns dangerous tasks to domestic workers. As for the regulations on privatesector workers, the change of employer can be done with the employers' permission as long as the worker has worked for at least one year. However, private-sector workers can change sponsors or employers if: The employer does not renew the worker's residence permit; the 
The urgency to reform the kafāla system in the sake of human...(Anggita Doramia Lumbanraja, et.al)

employer does not pay the worker for three consecutive months (International Labour Organization (ILO), 2019).

Based on the comparison between the regulation of workers in the private sector and migrant workers described above, the protection of the rights of domestic workers is weaker than that of workers in the private sector. Although it must be admitted that both regulations have not met the demands of workers' rights in the ILO Conventions. Issues that need to be considered, especially in the rules governing domestic workers, namely: recruitment fees charged to workers, confiscation of passports by the employer, which is not expressly prohibited, does not regulate the minimum wage (this may make employers accessible at will, providing inhumane wages), very long working hours (above 15 hours) but not clearly regulated regarding rest periods, and no provisions regarding overtime pay. Unscrupulous employers can exploit the absence of clear and firm rules to employ domestic workers inhumanely.

The Kafäla system is under pressure for reform from the international community and human rights organizations. Human rights organizations, the International Labor Organization (ILO), and the International Organization for Migration (IOM) have found that the modern Kafäla system is being abused by the relevant parties, which is incompatible with fundamental human rights. Therefore, when the UN High Commissioner for Human Rights, Navi Pillay, visited the GCC Countries in 2010, he argued that the Kafala system was a modern form of slavery. International conventions prohibit this because they deprive foreign workers of fundamental rights and contradict the Universal Declaration of Human Rights (Malaeb, 2015, p. 308).

The Kafäla system causes, facilitates and perpetuates human rights violations in several concrete ways that exploit migrant workers. Both men and women suffer the abuse caused by the Kafäla system, although the specifics vary by gender. The Kafäla system creates a sense of control by employers over workers. The most common control methods are passport confiscation and “withholding workers' wages in arrears” (Sönmez et al., 2011).

Migrant workers suffer from other forms of harassment and violations of their rights, such as unpaid or underpaid wages, confiscation of passports, inadequate living conditions, long working hours, agency and recruitment fees charged to workers, replacement of 
contracts, and freedom of movement limited or non-existent, physical, sexual or emotional abuse, and abandonment in the event of bankruptcy (Asia Pacific Mission for Migrants, 2014, p. 29).

The practice of abusing the Kafäla System leads to the violation of several articles in the UDHR, including the provisions of Article 4 (free from slavery), Article 5 (free from torture and cruelty), Articles 7-8 (equality and legal aid), Articles 9-10 (fair trial law, Article 12 (protection of personal and family affairs), Article 17 (possession of property), and Article 22-25 (right to social security, employment, decent wages, and welfare). This Kafäla also contradicts Article 8 of the ICCPR (International Covenant on Civil and Political Rights), prohibiting slavery and/or forced labor. After the fall of Islam, slaves were treated as fellow human beings with special rights. The Prophet freed slaves who were subjected to cruel treatments. The Qur'an mentions in many verses about the liberation of slavery as mentioned in 5. QS. Al-Ma'idah verse 89. Apart from violating Article 8 of the ICCPR, abuse of System Kafäla also contradicts Articles 9-10 (individual freedom and security), Article 12 (freedom of mobility from one area to another) (Azhari, 2016, p. 68).

Therefore, the Government of Saudi Arabia should immediately ratify such as the Convention on the Elimination of All Forms of Discrimination Against Women and its Protocols ("CEDAW"), the International Convention of the Elimination of All Forms of Racial Discrimination (“ICERD”), ILO Convention No. 100 on Equal Remuneration; ILO Convention 105 on the Abolition of Forced Labor; ILO Convention No. 29 Concerning Forced or Compulsory Labor; and ILO Convention No. 111 on Non-Discrimination in Employment and Occupation (International Trade Union Confederation (ITUC), 2017, p. 17). This must be supported by the efforts of the Indonesian government to establish good communication with the Government of the Kingdom of Saudi Arabia to encourage them to ratify these conventions for the benefit of Indonesian Domestic Workers in Saudi Arabia.

\section{The urgency to reform the kafäla system}

Based on the discussion results above, the issue of actually reforming the Kafala system must be addressed. This is due to the growing abuse of the Kafäla system, which is contrary 
The urgency to reform the kafāla system in the sake of human...(Anggita Doramia Lumbanraja, et.al)

to Shariah and Human Rights.

The reforms enacted by the Government of Saudi Arabia in March 2021, of course, are not aimed at eliminating the practice of violating the rights of Foreign Domestic Workers. Therefore, the Government of Saudi Arabia must seriously reform the Kafäla System for Foreign Domestic Workers. This must be preceded by ratification of the relevant international conventions. Then, the Government of Saudi Arabia should change Resolution No.310 of 2013 on the Household Regulation on Services Workers and Similar Categories, accommodating the provisions of ILO Convention No. 189.

The recruitment process for Domestic Workers should be formalized and monitored to protect the rights and welfare of migrant workers. The reform of the Kafäla system should stop the individual sponsorship system and replace it with a unique guarantee institution under the supervision of the government under the Ministry of Human Resources and Social Development of Saudi Arabia so that the Government of Saudi Arabia should be fully responsible for the entry, transfer, and departure of Migrant Workers. Thus, the migrant worker will make a contract with the Government through the Minister, just as the employer will pay the salary to this institution. The same applies to work visa requirements. Work visas should not be placed at the discretion of individual sponsors. Instead, it is submitted to a particular labor guarantee agency.

In addition, the Government of Saudi Arabia should guarantee the right of Migrant Workers to produce freely, keep and control their passports, travel documents, and mobile phones at all times without any confiscation by the Employer. Severe penalties should be applied to employers who do not comply with these regulations. In addition, the fundamental human rights of migrant workers to freedom of movement must be upheld, especially for migrant domestic workers who should not be forcibly confined at home. This is to enforce the provisions in Articles 9-12 of the ICCPR to ensure the freedom of migrant workers.

Labor law reforms related to workers' freedom to replace Kafil should also apply to Foreign Domestic Workers. Because Foreign Domestic Workers are the group most vulnerable to abuse by their employers and even vulnerable to becoming victims of the Trafficking in Persons Syndicate network. Resolution 310 should contain this guarantee of 
Ijtihad: Jurnal Wacana Hukum Islam dan Kemanusiaan, Volume 21, No. 2, Desember 2021: 213-230

freedom to protect Foreign Domestic Workers from slavery practices and become victims of the Trafficking in Persons Syndicate network.

\section{Indonesia legal policies plans to stimulate the kafāla system reform}

The Indonesian government has pursued various policies to protect and prevent all forms of violation of the rights of Indonesian Migrant Workers. On October 10, 2010, the Governments of Indonesia and Saudi Arabia signed a cooperation agreement to establish a bilateral one-track placement system for Pekerja Migran Indonesia (PMI) or Indonesian migrant workers in the household sector or domestic workers. This system is called Sistem Penempatan Satu Kanal (SPSK) or the one channel placement system.

This system is a forerunner that should be developed. And this is an opportunity for the Government of Indonesia to supervise the process of placing Indonesian Migrant Workers in Saudi Arabia. Supposedly, this SPSK could be a forum for the Government of Indonesia to urge the Government of Saudi Arabia to create a special guarantee institution integrated into the SPSK system. By conducting bilateral cooperation ( $G$ to $G$ ), the Government of Indonesia should approach and communicate to form a special guarantee institution aimed at Indonesian Migrant Workers in Saudi Arabia, including Workers who will work as Domestic Workers. This special guarantee institution is a representative institution from the ministry of workforce from both countries, which will be accommodated in one institution. So later together, the two countries will carry out supervision through this SPSK. So the Kafäla system shifted from individual guarantees to guarantees carried out by government representatives. Because the protection of labor rights is an obligation of each country, wherever its citizens are. Therefore, SPSK is a good forum for forming a special agency for labor guarantees in Saudi Arabia.

This particular agency for labor insurance is intended to overcome the asymmetric information phenomenon so far. The information obtained by the Indonesian side is often inversely proportional to the facts that happened to Indonesian Migrant Workers in Saudi Arabia. So that with the advancement of technology and SPSK, this asymmetric information problem should be expected to be resolved. 
The urgency to reform the kafāla system in the sake of human...(Anggita Doramia Lumbanraja, et.al)

The Kafäla system, from a philosophical point of view, brings many benefits, and this is by the principle of guarantee in labor law and immigration law. However, indeed we cannot turn a blind eye to the practices of irresponsible parties' misuse of the Kafäla system. Concerns about the Kafal system leading to the practice of slavery and the perpetuation of the criminal act of trafficking in persons, of course, must be considered. Especially the Indonesian government, which has been dealing with many cases of Indonesian Migrant Workers in Malaysia.

Ministerial Regulation Number 260 of 2015 concerning Termination and Prohibition of Placement of Tenaga Kerja Indonesia (TKI) on Individual Users to the Middle East region is still being violated by many parties for reasons of economic interest. This indicates that it is difficult to stop the distribution of Migrant Workers to work as Domestic Workers in the Middle East Region, including Saudi Arabia. Therefore, the Government must create a system that supports the access of the Indonesian Government to be able to carry out full supervision of Indonesian Migrant Workers in Saudi Arabia. The Government of Indonesia must actively communicate and approach to encourage the Government of Saudi Arabia to ratify several international conventions that stimulate the making of laws and regulations that can protect Indonesian Migrant Workers in Saudi Arabia.

The Government of Indonesia, through the Consulate General, must actively advocate and monitor the condition of Indonesian Migrant Workers in Saudi Arabia, especially those working in the domestic sector. Therefore, the sending of human resources to carry out these efforts to the Indonesian Consulate General in Saudi Arabia must be increased to make these efforts effective.

\section{Conclusion}

The Kafäla system is a guarantee system for workers in Saudi Arabia. In practice, it is often misused by the Suppliers and Employers to lead to the practice of slavery, human rights violations, and trafficking in persons. Indonesian Migrant Workers in Saudi Arabia also experience this practice. From the perspective of Islamic law, it is contrary to the philosophical values of maqāsid ash-syariah, especially to the benefit of the soul, the benefit of the property, and the benefit of the descendants of Indonesian Migrant Workers. 
Meanwhile, from the perspective of International Law, the misuse of the Kafal System is contrary to UDHR Articles 4, 5, 7, 7, 9, 10, 12, 17, 22, 23, 24, and 25, as well as ICCPR Articles 8, 9, 10, and 12. This is based on the fact that the Government of Saudi Arabia has not ratified several international conventions that support the protection of the rights of Migrant Workers, especially in the Domestic sector. Resolution 810 does not adequately provide the protection that Migrant Workers who work in the Domestic sector should receive. Therefore, the Government of Indonesia should make a Cooperation agreement with Saudi Arabia to establish a Special Guarantee Agency for Indonesian Migrant Workers in Saudi Arabia. So, the practice of the Kafāla System no longer places the Employer as Kafil but gives the Kafil position to this special guarantee institution. This institution is a bilateral representative from Saudi Arabia and Indonesia integrated with SPSK. It is hoped that this will stimulate the Government of Saudi Arabia to play a more active role in paying attention to, protecting, and accommodating the interests of Migrant Workers in its territory. And through this institution, the Government of Indonesia has access to participate in supervising to pay attention to the conditions of Indonesian Migrant Workers in Saudi Arabia.

\section{References}

Al-Ghanim, K. (2015) “Kafāla System Remains Resilient in the GCC,” in Al-Atiqi, S. (ed.) Gulf Affairs: Labor Market Dynamics in the GCC States. Autumn 2015. Oxford: OxGAPS Forum, pp. 6-8.

AlShehabi, O.H. (2021) "Policing labour in empire: the modern origins of the Kafāla sponsorship system in the Gulf Arab States," British Journal of Middle Eastern Studies, 48(2), pp. 1-20.

Alzahrani, M.M. (2014) "The System of Kafāla and the Rights of Migrant Workers in GCC Countries - With Specific Reference to Saudi Arabia," European Journal of Law Reform, 19(6), pp. 171-194.

Asia Pacific Mission for Migrants (2014) The Kafala: Research on the Impact and Relation of the Sponsorship System to Migrant Labor Bondage in GCC Countries. September 2014. Edited by R. Bultron. Hong Kong SAR: ASIA PACIFIC MISSION FOR MIGRANTS. 
The urgency to reform the kafāla system in the sake of human...(Anggita Doramia Lumbanraja, et.al)

Azhari, A. (2016) "The Kafāla Sponsorship System In Saudi Arabia: A Critical Analysis From The Perspective of International Human Rights And Islamic Law," The SOAS Journal of Postgraduate Research, 10, pp. 61-80.

Baldwin-Edwards, M. (2011) "Labour immigration and labour markets in the GCC countries: national patterns and trends," LSE Kuwait Programme Research Paper, 15, pp. $1-65$.

Dahlan, Z. et al. (1999) Filsafat Hukum Islam. 3rd edn. Jakarta: Bumi Aksara.

Diop, A., Johnston, T. and Le, K.T. (2015) "Reform of the Kafāla System: A Survey Experiment from Qatar,” Journal of Arabian Studies, 5(2), pp. 116-137.

Foster, N.H.D. (2001) “The Islamic Law of Guarantees," Arab Law Quarterly, 16(2), pp. $133-157$.

Hanif, A. (2019) "Akad Kafālah Dalam Perspektif Filsafat Ditinjau dari Asas Kemaslahatan," Tabkim: Jurnal Hukum dan Syariah, 15(1), pp. 88-97.

Human Right Watch (HRW) (2021) Saudi Arabia: Labor Reforms Insufficient Abusive Elements Remain; Changes Exclude Domestic Workers.

International Labour Organization (ILO) (2019) Regulatory Framework Governing Migrant Workers, International Labour Organization (ILO).

International Trade Union Confederation (ITUC) (2017) Facilitating Exploitation: A review of Labour Laws for Migrant Domestic Workers in Gulf Cooperation Council Countries. Brussels. al Jazeera (2020) "Saudi Arabia to remove key restrictions on foreign workers," 4 November. al Jazeera (2021) “Saudi Arabia announces changes to Kafāla system,” 14 March.

Jureidini, R. and Hassan, S.F. (2020) “The Islamic Principle of Kafāla as Applied to Migrant Workers: Traditional Continuity and Reform," Migration and Islamic Ethics, 2(Residence, Naturalization and Citizenship), pp. 92-109.

Kirom (2021) "Kisah Pilu Arini, Dilecehkan dan Diperjualbelikan Majikan Saat jadi TKW di Saudi," Merdeka.com, 19 May.

Kurniawan, E. (2018) “Distorsi Tehadap Maqāṣid Al-Syarīah Al-Syā’ibī Di Indonesia,” AlRisalab: Forum Kajian Hukum dan Sosial Kemasyarakatan, 18(2), pp. 175-194.

Lloyd, W.H. (1917) “The Surety," University of Pennsylvania Law Review and American Law Register, 66(1), pp. 40-68. 
Ijtihad: Jurnal Wacana Hukum Islam dan Kemanusiaan, Volume 21, No. 2, Desember 2021: 213-230

Malaeb, H.N. (2015) “The 'Kafala' System and Human Rights: Time for a Decision,” Arab Law Quarterly, 29(4), pp. 307-342.

Migrant Forum in Asia (MFA) (2012) Policy Brief No. 2: Reform of The Kafäla (Sponsorship) System. Phillipines.

Murray, H.E. (2012) "Hope for Reform Springs Eternal: How the Sponsorship System, Domestic Laws and Traditional Customs Fail to Protect Migrant Domestic Workers in GCC Countries,” Cornell International Law Journal, 45(2), pp. 462-485.

Okezone (2021) "Sistem Kafāla di Arab Saudi, Ratusan TKI Hilang Kontak dari Keluarga," Okezone.com, 20 March.

Putranto, P.D. (2018) “Kisah Sumiyati, TKI dari Grobogan yang Tewas Dianiaya Majikannya di Arab Saudi ," Kompas.com, 11 January.

Robinson, K. (2021) What Is the Kafala System?, Council on Foreign Relations.

Shaham, D. (2008) "Foreign Labor in the Arab Gulf: Challenges to Nationalization," Al Nakhlah: The Fletcher School Online Journal for Southwest Asia and Islamic Civilization, (Fall), pp. 1-13.

Silvey, R. and Parreñas, R. (2020) "Precarity chains: cycles of domestic worker migration from Southeast Asia to the Middle East," Journal of Ethnic and Migration Studies, 46(16), pp. 3457-3471.

Sönmez, S. et al. (2011) "Human rights and health disparities for migrant workers in the UAE," Health and Human Rights: An International Journal, 13(2).

Suhendi, H. (2002) Fiqh Muamalah. Jakarta: Raja Grafindo Persada.

Wehr, H. (1994) A Dictionary of modern written Arabic. 4th edn. Edited by J.M. Cowan. Ithaca: Spoken Language Services.

Winckler, O. (2010) Labor Migration to the GCC States: Patterns, Scale, and Policies, Middle East Institute. 